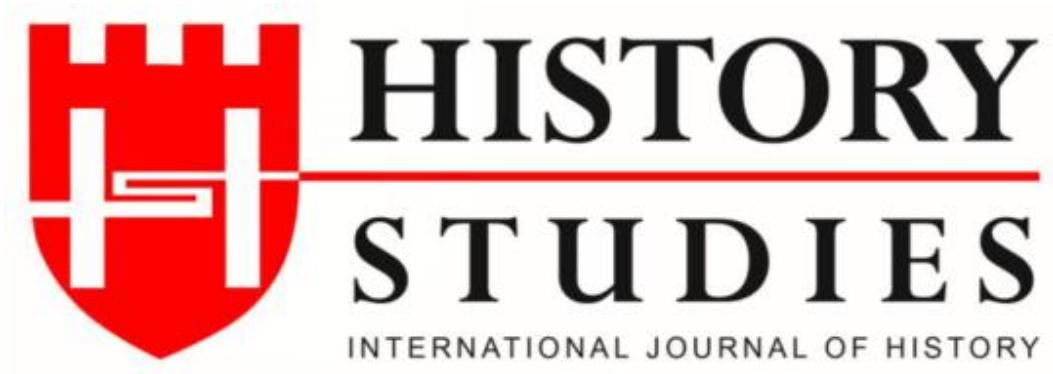

ISSN: 13094173 (Online) 1309 - 4688 (Print)

Volume 10 Issue 9, p. 189-205, December 2018

DOI Number: 10.9737/hist.2018.682

\title{
1260-61 / 1844-45 Temettuat Kayıtları Ișığında Tatlucak Köyünün Sosyal ve Ekonomik Yapısı ${ }^{1}$ \\ 1260-61 / 1844-45 Social and Economic structure of Tatlucak Village in the Light of Temettuat Records
}

\author{
Doç.Dr. Rafet METIN \\ (ORCID: 0000-0002-2164-4994) \\ Kırıkkale Üniversitesi - Kırıkkale
}

\begin{abstract}
Öz: Temettuat Defterleri XIX. yüzyll Osmanl sosyal ve ekonomik tarihinin önemli kaynaklarından biridir. Vergi kaynakların yeniden tespit ederek halkın üzerindeki vergi yükünü hafifletmek ve vergi dağılımında yaşanan adaletsizliği önlemek amacıyla hazırlanan temettuat kayıtları sosyo-ekonomik ve demografik yapının da ortaya konulmasında önemli bilgiler sunmaktadır. Kayıtlarda anılan dönemde bölgelerin mal-mülk, hayvan, arazi ve insanların șahsi mal varlıklarının kaydedilmesi ile sosyo-ekonomik hayat, nüfus ve tarımsal ekonomi ile ilgili bütün karakteristik özellikler ortaya konulmaktadır. Kayıtlarda ayrıca mükelleflerin adları, lâkapları, meslekleri hakkında da bilgi alabilmek mümkün olmaktadır. Bu çalışmada, H.1260-1261/M.1844-1845 yılında Dinek Keskini Kazasina tabi Tatlucak karyesinin 710 numaral temettuat defterinden faydalanilarak, sosyal ve ekonomik yapısı ortaya konulmaya çalışılmıştır. Toplam 20 hanesi olan karyede sakin olan insanların geçimlerini büyük ölçüde tarım ve hayvancılıktan sağladıkları anlaşılmaktadır. Köyde tarımsal manada buğday, arpa ve penbe (pamuk) üretimi yapılmaktadır. Hayvancılık alanında ise daha çok küçükbaş- büyükbaş hayvanlar ile yük ve binek hayvanları yetiştirilmektedir. Meslek dalı olarak ziraat erbabının fazlalığ dikkat çekmektedir. Bunun yanında, imam, hizmetkâr ve çoban gibi meslek kollarında görev yapan kimselerinde olduğu kayıtlardan anlaşılmaktadır. Köyde vergi mükellefi hane reislerinin tarım, hayvancllık ve meslek gelirleri ile birlikte ödemiş olduklarl vergi çeşitleri tespit edilerek vergi yükleri de ortaya konulmaya çalışılmıştır.
\end{abstract}

Anahtar Kelimeler: Tatlucak karyesi, Temettüat Defteri, Mesleki Yapılanma.

Abstract: Temettuat registers are one of important sources of Ottoman's social and economic history. Temettüat records have been prepared in order to reduce the tax burden on the people and to prevent injustice in the tax distribution by re-determining the tax sources. In addition, these records provide important information for the socio-economic and demographic structure. In the period referred to in the records, all characteristics of socio-economic life, population and agricultural economy are revealed by registering the properties, animals, lands and persons' personal wealth of regions. In these records, it is also possible to get information about taxpayers' names, nicknames, and occupations. In this study, benefiting basically 710 numbered temettuat record of Tatlucak village which is within in the boundaries of Dinek Keskin district in year of H.1260-1261/M.1844-1845, it is tried to reveal social and economic structure. It is understood that people provide their livelihood largely from agriculture and animal husbandry in the village which consist of 20 families. In terms of agriculture, wheat, cotton and barley production is being done in the village. In the field of animal husbandry, mostly small cattles, bovine animals, draught animals and mount animals are grown. As field of profession, the surplus of agricultural staff is remarkable. Besides, it is understood from records that there are different field of professions like imams,

\footnotetext{
${ }^{1}$ Bu çalışma 4-7 Nisan 2018'de International Congress Of Eurasian Social Sciences'ta sözlü bildiri olarak sunulmuştur.
} 
servants and shepherds in the village. It is also tried to reveal the burden of tax of taxpayers by determining agriculture, husbandry and occupation revenue and kind of tax which is paid by them.

Anahtar Kelimeler: Tatlucak village, Temettüat Register, Occupational Structuring.

\section{Giriş}

Temettü' kâr etmek anlamına gelen Arapça bir kelimedir. Temettüat ise; kârlar, kazançlar anlamına gelmektedir. ${ }^{2}$ Tanzimat'a kadar değişik adlarla halktan alınan vergilerin yerine getirilen Temettû vergisinin kaydedildiği defterlere, "Temettuat Defterleri” adı verilmiştir. Bu defterler 19. yüzyıl ortalarında Osmanlı Devleti'nin içinde bulunduğu iktisadi, sosyal ve ticari hayatı ortaya koymaktadır. ${ }^{3}$ Temettuat defterleri genel itibariyle bir bölgenin demografik yapısı, hane reisinin menkul ve gayr-i menkul kaynakları, yıllık kazancı, işletmelerin büyüklügüu, iş gücü ve ayrıntılı vergi yükü, kişilerin mesleği, yetiştirilen ziraî ürün ve hayvanlar ileticarî ve sınaî müesseseler hakkında bilgiler sunmaktadır. ${ }^{4}$ Ayrıca anılan defterlerden Osmanlı ülkesinde yaşayan nüfusun yerleşim düzeni, zirai üretim durumunu, hanelerin servet ve gelirleri ile vergilendirme konularında çok zengin bilgiler elde etmek mümkün olmaktadır. ${ }^{5}$ Kısaca bu defterlerden bir bölgenin Demografik etnik yapısı, fert düzeyinde menkul ve gayr-i menkul kaynaklar, ferdin yıllık kazancı, işletmelerin büyüklüğü, toplam ve ayrıntılı vergi yükünü, işgücünü, kişilerin mesleği, yetiştirilen zirai ürün ve hayvanlar, Ticari ve sınai müesseseler hakkında önemli veriler elde edilmektedir ${ }^{6}$. Temettuat defterleri 1840 ve 1844-45 yıllarında hazırlanmıştır. 1840 yılında tutulan temettuat defterleriyle 1844-45 yıllarında tutulanlar arasında muhteva ve düzen bakımından bazı farklılıklar bulunmaktadır. Her iki yıla ait sayımlarda da başa hane ve numara yazılırken altlarına da rakamlar konulmuştur. Bunlardan birincisi defterdeki kaçıncı hane olduğunu belirtmek için yazılmışken, ikincisi ise hane içindeki kaçıncı aile olduğunu göstermek maksadıyla yazılmıştır. Örneğin aynı hane numarası altında "Mehmed oğlu Hüseyin" üzerinde "1" numara, eğer yer uygunsa hemen yanında "oğlu Hüseyin oğlu Mehmed" üzerinde "2" numara bulunmaktadır. Bu numara bazen "3"e de yükselebilmektedir. Defterlerin bazılarında sayfalar çift sütun olarak düzenlenmiş olup bazılarında ise bu şekil, sadece emlak ve malı az olan hane reisleri için kullanılmıştır. ${ }^{7}$

Defterlerde her hanenin mal varlı̆̆ yazıldıktan sonra, toplam vergi miktarı da belirtilmiştir. Bunun dışında hane reisinin bir önceki sene vermiş olduğu temettü vergisi ile öşür ve rüsum miktarı ve bir sonraki yıl vermesi gereken tahmini temettü vergisi yazılmıştır. Kiraya verilen gayrimenkullerde de aynı şekilde kayıtların yapıldığı, yıllık kira geliri ve buna karş1lı ödenmesi gereken temettü miktarı ile bir sonraki yıl ödenmesi gereken tahmini temettü miktarı kaydedilmiştir. Ayrıca, defterlere her mahalle veya köyün yazımı bittikten sonra buradan alınacak vergi ve toplam temettü miktarı defter sonlarına yazılmıştır. ${ }^{8}$ Defterlerde,

\footnotetext{
${ }^{2}$ Ferit Devellioğlu, "Temettü'-Temettüat", Osmanlıca - Türkçe Ansiklopedik Lügat (13. Baskı.) Ankara: Aydın Kitabevi Yayınları,1996. s.1073

${ }^{3}$ Mübahat Kütükoğlu, “Osmanlı Sosyal ve İktisadî Tarihi Kaynaklarından Temettü Defterleri”, cilt LIX/225, Belleten, Ankara 1995. s. 395.

${ }^{4}$ Abdulkadir Gül, Temettuat Defterlerine Göre Pasinler'in (Hasankale) Sosyal ve Ekonomik Yapısı . Karadeniz Araştırmaları, 6 (23):2009.s.81.

${ }^{5}$ Tevfik Güran, “19. Yüzyll Temettuat Tahrirleri”, Osmanlı Devleti’nde Bilgi ve İstatistik, Ankara,2000.s.78.

${ }^{6}$ İlbeyi Özer, Temettuat Defterlerinde Somuncu Babanın Nesebi (1844),Akademik Araştırmalar Dergisi , 2000 s.4-5:s.596.

${ }^{7}$ Kütükoğlu,age,s.395-998.

${ }^{8}$ Kızılkan, A. Ö., "Osmanlı Vergi Düzeninde Temettuat Uygulamaları Üzerine Bir Değerlendirme”, Dumlupınar Üniversitesi Sosyal Bilimler Dergisi, sayı:20, 2008.s.60-61.
} 
mahallelerdeki toplam hane sayısı, arazi miktarı, hane reislerinin meslekleri, yükümlü oldukları vergi miktarları gibi birçok konuda teferruatlı bilgiler bulunmaktadır. Ayrıca her hane reisinin adı ve unvanı, sahip olduğu mal varlı̆̆1, ne kadar emlak ve arazisi olduğu ve bu arazinin ekili olan bölümleri ayrıntılı biçimde ele alınmıştır. Meslekler, hane reisinin isminin üzerine eğik olarak yazılmıştır. Tarımla geçinen hane reisinin meslek bölümü "erbab-1 ziraattan idüğ̈̈", esnaflıkla geçinenlerinki ise "erbab-1 ticaretten idüğü" olarak belirtilmiştir. Ticaret ve ziraatın her ikisiyle geçimini sağlayanlar "erbab-1 ziraat ve ticaretten idügü̈" şeklinde belirtilmiştir

Çalışmamızın ana kaynağını teşkil eden Temettuat Defterlerinden BOA, ML VRD.TMT. 710 numarada kayıtlı "Dinek Keskini kazasına tabi Tatlucak karyesinin sosyal ve ekonomik yapısı ortaya konulmaya çalışılmıştır. Çalışmada Tatlucak köyünün nüfusu ile birlikte köyde kullanılan isimler, lakaplar, meslekî yapılanma, köyde yaşayan hane reislerinin tarım, hayvancılık ve meslek gelirleri ile birlikte ödemiş oldukları vergi çeşitleri tespit edilerek vergi yükleri ortaya konulmaya çalışılmıştır. Temettuat defterleri halen Başbakanlık Osmanlı Arşivi'nde muhafaza edilmekte, Maliyeden Müdevver Defterler ve Kamil Kepeci tasnifleri içerisinde yer almaktadır. Temettuat defterleri, Maliye Nezareti Varidat Kalemi defterlerinden olup, tasnif ve kataloglanmasında, o tarihteki idari taksimat esas alınmıştır. Bu defterler, içerikleri esas alınarak alfabetik olarak sınıflandırılmış, her eyalet de kendi içinde yine alfabetik olarak kazalara ayrılmıştır. Sınıflandırılan defterlere sıra numarası verilerek dokuz adet katalogda toplanmıştır. ${ }^{9}$

XVI. yüzyılda Tatlucak karyesinin de içinde bulunduğu bölgenin Osmanlı idari teşkilatındaki yeri fazla bir değişiklik göstermeden günümüze kadar gelmiştir.Anılan tarihte Bahşılı ve Karakeçili ilçeleri topraklarının tamamı ile Yahşihan ilçesinin batısının, yani Kızılırmak'ın Ankara yakasındaki topraklarının, Ankara Sancağı merkez kazasına bağlı olduğunu görürüz. ${ }^{10}$ Hasandede, Yahşihan, Kırıkkale merkez, Balışeyh merkez ve ilçenin batı kısımları, Koçubaba, Sulakyurt merkez ve ilçenin batı kısımları "Kalecik Keskini Kazası" adıyla Çankırı Sancağı'na bağlıdır. Delice ırmağının doğu kısımları "Deliceözü Nahiyesi" adıyla Bozok Sancağı'na, Balışeyh ilçesinin ve Sulakyurt ilçesinin doğu kısımları ile Delice ilçesinin tamamı, Büyükafşar, Büyükyağlı, Çerikli, Aşağı Mahmutlar, Keskin merkezinin kuzey ve doğusunda kalan kısımları "Keskin Nahiyesi" adıyla Kırşehri Sancağı'na, Ahili, Köprüköy, Çelebi, Kazmaca ve muhtemelen Keskin merkez olmak üzere Ankara-Kayseri karayolunun güneyinde kalan kısımlar Kızılırmak'a kadar "Dinek Nahiyesi" adıyla Kırşehri Sancağı'na bağlıdır. ${ }^{11}$ Daha sonraki yıllarda bir takım idari değişiklikler vukubulmuştur, ancak genel olarak XVI. yüzyıldaki bu teşkilatlanma yürürlükte kalmıştır.

\section{Tatlucak Karyesi}

\subsection{Nüfus}

Tatlucak karyesinin nüfusu ile ilgili olarak 669 numaralı temettuat defterinden tespit ettiğimiz kadarı ile1845 yılında Kırlangıç karyesinin 20 haneye tekâbül eden 100 neferlik

\footnotetext{
9 Mustafa Serin, “Osmanlı Arşivi’nde Bulunan Temettuat Defterleri” T.C. Başbakanlık I.Millî Arşiv Şûrası (20-21 Nisan 1998) Tebliğler Tartışmalar, T.C. Devlet Arşivleri Genel Müdürlüğü Yayınları, Ankara 1998, s.717-718.

${ }^{10}$ Ahmet Kankal, Kırıkkale Tarihine Dair Araştırmalar I: İskân, OTAM, Sayı: 9: 1998.s.235.

${ }^{11}$ Kankal,age.s.236-237.
} 
nüfusu söz konusudur. ${ }^{12}$ Günümüzde Kırıkkale'nin Delice ilçesine bağlı olan köyün 2000 yı1ı adrese dayalı nüfus tesbitine göre nüfusu 175 olarak belirlenmiştir.

Tablo 1. Tatlucak Karyesinde 1845-2000 Yıllarındaki Tahmini Nüfus

\begin{tabular}{|l|l|}
\hline Y1llar & Tahmini nüfus \\
\hline 1845 & 100 nefer \\
\hline 2000 & 175 \\
\hline
\end{tabular}

\section{2.Şahıs Adları ve Kullanılan Lakaplar}

710 numaralı temettüat defterinde hane reislerinin isimleri babalarının adları ve lakaplarıyla birlikte yazılmıştır. Bu nedenle köyde yaygın olarak kullanılan baba ve oğul isimlerini tespit etmek mümkün olmuştur.

Tablo 2:Tatlucak Karyesinde Kullanılan Şahıs İsimleri

\begin{tabular}{|c|c|c|c|}
\hline İsim & Say1 & $\%$ & 불 \\
\hline Ali & 5 & 17.2 & $\frac{\text { HISTORY }}{\text { STUDIES }}$ \\
\hline Aşır & 3 & 10.3 & 192 \\
\hline Mehmed & 2 & 6.8 & $\begin{array}{l}\text { Volume } 10 \\
\text { Issue } 9\end{array}$ \\
\hline Hüseyin & 2 & 6.8 & $\begin{array}{c}\text { December } \\
2018\end{array}$ \\
\hline Emin & 1 & 3.4 & \\
\hline Mustafa & 1 & 3.4 & \\
\hline Süleyman & 1 & 3.4 & \\
\hline
\end{tabular}

${ }^{12}$ Ömer Lütfi Barkan, (1953). Tarihî demografi araştırmalart ve Osmanlı tarihi (Cilt: X). İstanbul: Türkiyat Mecmuası.1953.s.12.( Bu hesaplama Ö.Lütfi Barkan'ın genel nüfusu bulmak için en çok kullanılan yöntem olan "hâne x 5 " formülünden yola çıkılarak yapılmıştır 


\begin{tabular}{|c|c|c|}
\hline Yusuf & 1 & 3.4 \\
\hline Musa & 1 & 3.4 \\
\hline Tercan & 1 & 3.4 \\
\hline Musa & 1 & 3.4 \\
\hline Kalender & 1 & 3.4 \\
\hline Şah Murad & 1 & 3.4 \\
\hline Ali İmam & 1 & 3.4 \\
\hline Zarife & 1 & 3.4 \\
\hline Toplam & 29 & \\
\hline
\end{tabular}

Tablo 2'de yer alan verilerden anlaşıldığ üzere Tatlucak karyesindeki vergi nüfusunun tamamına yakını erkektir. Sadece köyün 15 numaralı hanesinde ikamet eden Zarife oğlu Veli anne adı ile anılmaktadır. ${ }^{13}$ İsimleri incelediğimizde Peygamber ve onun ehl-i beyti başta olmak üzere daha çok Arapça kökenli isimlerin olduğu görülmektedir. Birinci sırada Ali ismi gelmektedir. Ali ismi toplam isimlerin \%17.2'sini teşkil etmektedir. İkinci sırayı \%10.3 ile Aşır ismi yer almaktadır. Üçüncü sırayı ise \% 6.8 ile Mehmed ve Hüseyin isimleri gelmektedir. Tabloda zikredilen isimler arasında Tercan ve Kalender gibi isimler o dönemde yörede kullanılan ender isimler olarak karşımıza çıkmaktadır.

\subsection{Tatlucak Karyesinde Kullanılan Lakaplar}

Tatlucak'ta hane reislerinin toplumda tanınmasını sağlayan aile ve sülale adlarının Tablo3 'te yer alan köse, şah, milcan, tercan gibi lakaplar ise muhtemelen ailelerin geçmişten beri kullana geldikleri lakaplar olarak görülmektedir.

Tablo 3. Tatlucak'ta Kullanılan Lakaplar

\begin{tabular}{|c|c|c|}
\hline $\begin{array}{c}\text { Tercan oğlu Molla } \\
\text { Mustafa }\end{array}$ & Köse oğlu Halil & Köse oğlu Hüseyin \\
\hline Şah Murad oğlu Eyüb & Milcan oğlu Yusuf & $\begin{array}{c}\text { Ali İmamoğlu } \\
\text { Süleyman }\end{array}$ \\
\hline Köse oğlu Hanefi & Aşı oğlu Süleyman & Tercan oğlu Kalender \\
\hline Musa koca oğlu Mehmed & Zarife oğlu Veli & Ali İmamoğlu Ömer \\
\hline
\end{tabular}

${ }^{13}$ BOA, ML VRD.TMT,710. 


\subsection{Talucak Karyesinde Mesleki Yapılanma}

Toplam 20 hane olan köyde yaşayan insanların tamamı ziraat erbabındandır. Burada ilginç olan durum toplam 581 olan hayvan çeşitliliğine rağmen çoban mesleğini ya da 1 rgadlık mesleğini icra eden kimsenin bulunmamasıdır.

\subsection{Hayvancılık ve Hayvan Dağılımı}

Belgelerden anlaşıldığına göre 1845-1846 yıllarında Tatlucak karyesinde yaşayan haneler geçimlerini tarım ve hayvancılıktan sağlamakta idiler. Genel olarak süt ve süt ürünleri ihtiyaçlarını karşılamak için inek ve koyun, binek hayvanı ihtiyaçlarını karşılamak için merkep, çift sürmede faydalanabilmek için öküz kullandıkları anlaşılmaktadır.Tatlucak’ta toplam 581 olan hayvan varlığının büyük çoğunluğunu küçükbaş hayvanlar oluşturmaktadır.\%75.2'si küçükbaş (437 adet), \% 17.9'u büyükbaş (104 adet) ve \% 8.6's1 yük ve binek (50 adet) hayvanı olarak sıralanmaktadır. Büyükbaş hayvan çeşidinde, karasığır öküzü, sağman inek ve kısır inek ön planda yer alırken küçükbaş hayvan çeşidinde ise, koyun, keçi ve kuzu tercih edilmektedir.Binek ve yük hayvanı olarak ise merkep başta olmak üzere, deve, kısrak ve katır beslenmektedir.

Tablo 4. Tatlucak’ta Hane Reislerinin Sahip oldukları Hayvan Çeşitleri

\begin{tabular}{|c|c|c|c|}
\hline $\begin{array}{c}\text { Hayvan } \\
\text { çeşidi }\end{array}$ & Sayı & $\begin{array}{c}\text { Hayvan Sahibi } \\
\text { Hane }\end{array}$ & $\begin{array}{c}\text { Toplam Hane } \\
\text { Başına Düşen Baş }\end{array}$ \\
\hline Büyükbaş & 104 & 16 & 6.5 \\
\hline Küçükkbaş & 437 & 13 & 33.6 \\
\hline $\begin{array}{c}\text { Yük-Binek } \\
\text { Hayvanı }\end{array}$ & 50 & 16 & 3.1 \\
\hline Toplam Sayı & 581 & & \\
\hline
\end{tabular}

Tablo 5. Tatlucak’ta Hane Reislerinin Sahip oldukları Büyükbaş Hayvan Çeşitleri

\begin{tabular}{|c|c|c|c|}
\hline $\begin{array}{c}\text { Büyükbaş } \\
\text { Hayvan çeşidi }\end{array}$ & Sayı & $\begin{array}{c}\text { Hayvan Sahibi } \\
\text { Hane }\end{array}$ & Ortalama \\
\hline $\begin{array}{c}\text { Karası̆̆ı̆ı } \\
\text { öküzü }\end{array}$ & 36 & 16 & 2.25 \\
\hline Sağmal inek & 31 & 17 & 1.8 \\
\hline Kısır inek & 7 & 5 & 1.4 \\
\hline Düve & 7 & 6 & 1.6 \\
\hline Erkek Tosun & 1 & 1 & 1 \\
\hline Dişi buzağı & 1 & 1 & 1 \\
\hline
\end{tabular}




\begin{tabular}{|c|c|c|c|}
\hline Erkek buzağ & 21 & 14 & 1.5 \\
\hline Toplam & 104 & & \\
\hline
\end{tabular}

Büyükbaş hayvan söz konusu olduğunda köylerde çift sürme işinde ilk olarak akla at ve katır gücü gelmektedir.Ancak Talucak’ta öküzün ilk planda tercih edildiği görülmektedir. $\mathrm{Bu}$ durumun nedeni öküzün beslenme giderinin at ve katıra nazaran daha az olması ile izah edilebilir. Bir atı veya katırı bütün bir yıl boyunca arpa, yulaf, ot, kepek ve samanla beslemek gerekirken öküz yedi ay süre ile burçak ve samanla beslenebilmekte ve yılın geri kalan aylarında otlamak üzere çayırlara salıverilmektedir. Bu arada demetlerin tarladan harmana ve ürünün harmandan ambara taşınmasında at ve eşek gibi yük hayvanlarından da yararlanılmakla birlikte, daha çok bir çift öküzün çektiği iki tekerlekli kağnılar kullanılabilmektedir. ${ }^{14}$ Belgelerden anlaşıldığı üzere anılan dönemde Tatlucak'ta özellikle karasığır öküzü ahalinin tarım yaparken kullandığ 1 vazgeçilmez iş gücü kaynaklarından biri durumundadır. Köyde toplam 20 haneden 16 hanede karasığır öküzüne tesadüf edilmektedir.Belgelerden tespit ettiğimize göre köyde 3 hanede sağmal inek beslenmemektedir.Bunlar Köyün 7 numaralı hanesinde Köse oğlu Halil, 8 numaralı hanesinde kayıtlı Köse oğlu Hüseyin ve 16 numaralı henede kayıtlı Tercan oğlu Kalenderdir. ${ }^{15}$

Yük ve Binek Hayvanlarına gelince;Kırlangıç’ta 1845 yılında toplam 50 adet yük ve binek hayvanı bulunmaktadır.Bunlardan 17 tanesi merkep, 11 tanesi ise kısır kısrak 1 tanesi de sağmal katır 3 tanesi erkek katır, 14 tanesi dişi deve ve 2 tanesi erkek deve olarak tespit edilmiştir.

Tablo 6. Tatlucak’ta Hane Reislerinin Sahip oldukları Yük ve Binek Hayvanı Çeşitleri

\begin{tabular}{|c|c|c|c|}
\hline Hayvan çeşidi & Sayı & $\begin{array}{c}\text { Hayvan Sahibi } \\
\text { Hane }\end{array}$ & Ortalama \\
\hline Merkeb & 17 & 16 & 1.06 \\
\hline Kısır kısrak & 11 & 10 & 1.1 \\
\hline Sağmal katır & 3 & 2 & 1.5 \\
\hline Erkek katır & 3 & 3 & 3 \\
\hline Dişi deve & 14 & 7 & 1 \\
\hline Erkek deve & 2 & 2 & \\
\hline Toplam & 50 & & \\
\hline
\end{tabular}

\footnotetext{
${ }^{14}$ Nurgül Bozkurt, 1844-1845 Tarihli Temettuat Defterine Göre Kütahya Sancağı Dazkırı Kazası Evciler Köyünün Sosyal ve Ekonomik Yapısı, Uluslararası Sosyal Araştırmalar Dergisi, 4 (19): 2011.144.

${ }^{15}$ BOA, ML VRD.TMT,710:4,7.
} 
Küçükbaş hayvanlar bakımından bakıldığında Tatlucak'ta toplam 437 adet küçükbaş beslenmektedir. Toplam 20 hane olan köyde Sağmal keçi 11, sağmal koyun ise 7 hanede beslenmektedir.

Tablo 7. Tatlucak’ta Hane Reislerinin Sahip oldukları Küçükbaş Hayvan Çeşitleri

\begin{tabular}{|c|c|c|c|}
\hline $\begin{array}{c}\text { Küçükbaş } \\
\text { hayvan çeşidi }\end{array}$ & Sayı & Hane & Ortalama \\
\hline $\begin{array}{c}\text { Sağmal } \\
\text { koyun }\end{array}$ & 133 & 7 & 19 \\
\hline Sağmal keçi & 107 & 11 & 9.7 \\
\hline Kuzu & 166 & 4 & 41.5 \\
\hline Oğlak & 25 & 10 & 2.5 \\
\hline Toplam & 437 & & \\
\hline
\end{tabular}

\subsection{Arazi Dağılımı ve Toprak Kullanımı}

Tatlucak’ta hane reislerinin \% 93.4'ü (20) buğday ve arpa tarımı ile alakalı ziraî faaliyet içerisindedir. Köyde ikamet eden hanelerden \% 3.7'si penbe (pamuk) (20) ve \% 2.7 'si bağcrllk (19) ile iştigal etmektedir.

Tablo 8. Tatlucak’ta Ekili ve Dikili Tarım AlanlarınınDağılımı

\begin{tabular}{|c|c|c|c|c|}
\hline $\begin{array}{c}\text { Ekilebilir Arazi } \\
\text { Türü }\end{array}$ & $\begin{array}{c}\text { Miktar } \\
\text { (Dönüm) }\end{array}$ & Hane & Ortalama & $\%$ \\
\hline $\begin{array}{c}\text { Tarla (buğday- } \\
\text { arpa) }\end{array}$ & 838 & 20 & 41.9 & 93.4 \\
\hline Penbe(pamuk) & 34 & 20 & 1.7 & 3.7 \\
\hline Bağ & 25 & 19 & 1.3 & 2.7 \\
\hline Toplam & 897 & & & \\
\hline
\end{tabular}

\subsection{Gelirler}

\subsubsection{Tarım Gelirleri (Hasılatı)}

1844-1845 yılları arası Tatlucak'ta tarım topraklarına sahip 20 hane sahibinin hepsinin hasılat geliri vardır. Ekili (tarla) tarım alanları 872 dönüm olup 9.210 kuruş gelir elde edilmiştir. Ekili tarım alanlarından toplam 25 dönüm bağdan 2.070 kuruş gelir sağlanmıştır. Anılan tarihlerde daha önce yaptığımız bir çalışma olan Kazmaca karyesinde tarım 
topraklarına sahip 22 hane de ekili (tarla) tarım alanları 560 dönüm olup 9.985 kuruş gelir elde edilmiştir. Ekili tarım alanlarından toplam 37 dönüm bağdan 1.438 kuruş gelir sağlanmıştır. ${ }^{16}$

Tablo 9. Tatlucak'ta Ekili-Dikili Tarım Alanlarının Hasılatı

\begin{tabular}{|c|c|c|c|}
\hline $\begin{array}{c}\text { Ekilebilir Arazi } \\
\text { Türü }\end{array}$ & $\begin{array}{c}\text { Miktar } \\
\text { (Kuruş) }\end{array}$ & Miktar (Dönüm) & Ortalama \\
\hline $\begin{array}{c}\text { Tarla (buğday- } \\
\text { arpa) }\end{array}$ & 8.410 & 838 & 10.03 \\
\hline Bağ & 2.070 & 25 & 82.8 \\
\hline Penbe & 800 & 34 & 23.5 \\
\hline Toplam & 11.280 & 897 & \\
\hline
\end{tabular}

Temettuat defterlerinde köylüden alınan hububat öşrü verilerinden üretilen hububatların ne kadar olduğu tespit edilebilir.Öşür bölgelere göre değişmekle birlikte ortalama her ürün üzerinden $\% 10$ oranında alınmaktadır.Bu nedenle Tablo 10 'da vergiye esas olan toplam kilenin 10 katı alınarak toplam hububat üretimi tespit edilmeye çalışılmıştır.

Tablo 10. Tatlucak'ta Üretilen Toplam Hububat Miktarı

\begin{tabular}{|c|c|c|c|}
\hline $\begin{array}{c}\text { Ekilebilir Arazi } \\
\text { Türü }\end{array}$ & Kile $^{17}$ & Kile x 10 & Kg \\
\hline Hınta (Buğday) & 56 & 560 & 14.367 .36 \\
\hline Şair (arpa) & 29 & 290 & 6.452 .5 \\
\hline Penbe(Pamuk) & 16 & 160 & 3.560 \\
\hline
\end{tabular}

\subsubsection{Hayvancilık Hasılatı}

Tatlucak'ta tarımdan sonra ikinci sırada yer alan hayvancılık gelirleri 5.699 kuruş olarak tespit edilmiştir.

Tablo 11'deki veriler incelendiğinde görüleceği üzere, hayvancılık hasılatında ilk sırayı binek hayvanlar almaktadır (3.130 kuruş). İkinci sırada küçükbaş hayvanlar (1.629 kuruş) ve üçüncü olarak büyükbaş hayvanları gelmektedir (940 kuruş). Bu sıralamada dikkat çeken husus yük- binek hayvan fiyatlarının küçük ve büyükbaş hayvan fiyatlarından fazla olmasıdır.Belgelerden anlaşıldığına göre bu durumun nedeni köyde hem yük-binek hayvanı hemde taşımacılıkta da kullanılan dişi deve fiyatlarının yüksek olmasıdır.Köyde 1 sağmal ineğe 30 kuruş değer biçilirken 1 adet dişi deveye sağmal ineğin neredeyse 5 katı değer biçilmektedir. Köyün 5 numaralı hanesinde ikamet eden Aşır oğlu Ali’nin sahip olduğu 1 adet

\footnotetext{
${ }^{16}$ Rafet Metin, 1260-61 / 1844-45 Temettuat Kayıtları Işı̆̆ında Kazmaca Köyü, Studies of the Ottoman Domain Volume-Cilt: 8 / Issue-Say1: 15 /Date-Tarih: August Ağustos 2018.s.193.

${ }^{17} \mathrm{Bu}$ çalışmada hesaplamalar yapılırken buğday $1 \mathrm{kile}=25,656 \mathrm{~kg}$.; arpa ve penbe için ise $1 \mathrm{kile}=22,25 \mathrm{~kg}$. olarak alınmıştır.
} 
sağmal ineğine 30 kuruş değer biçilirken 1 adet dişi devesine 150 kuruş değer taktir edilmiştir. $^{18}$

Tablo 11:Tatlucak'ta hayvancılık hasılatı dağılımı

\begin{tabular}{|c|c|c|c|}
\hline Hayvan çeşidi & $\begin{array}{c}\text { Hasılat } \\
\text { miktarı } \\
\text { kuruş }\end{array}$ & Hayvan Sahibi Hane & Ortalama \\
\hline $\begin{array}{c}\text { Yük-Binek } \\
\text { Hayvanı }\end{array}$ & 3.130 & 16 & 195.6 \\
\hline Büyükbaş & 940 & 16 & 58.75 \\
\hline Küçükbaş & 1.629 & 13 & 125.3 \\
\hline Toplam Sayı & 5.699 & & \\
\hline
\end{tabular}

\subsubsection{Meslek Hasılatı}

1844-1845 yılları arasında Tatlucak’ta daha önce yaptı̆̆ımız köy çalışmalarından farklı olarak hizmetkârlık, ırgadlık ve çobanlık gibi mesleklerin olmayışıdır. Köydeki hanelerin tamamı ehl-i ziraat olarak kaydedilmiştir.Yıllık toplam temettüat bedelleri de 13.904 kuruş olarak belirtilmiştir. Sadece köyün 1 numaralı hanesinde kayıtlı olan ve muhtar olarak belirtilen Ali İmamoğlu İlyas kethüdanın toplam 1.455 kuruş olan temettüat miktarının 400 kuruşunu deve kirasından elde ettiği kaydedilmiştir. ${ }^{19}$

\subsection{Vergi-yi Mahsusa}

Temettu vergisinin esası Tanzimat'tan evvel II.Mahmut zamanında H.1241 (M.1826) tarihinde ihdas olunan "ihtisab resmi" dir. İhtisab resmi; şehriyye-i dekâkîn ve yevmiyye-i dekâkîn adıyla anılan vergilerle büyük yerleşim yerlerinde belediye geliri, pazar ve panayırlardan alınan damga, tartı, ölçü vs. vergileri, hile yapan esnafa kesilen para cezaları ve bütün yiyecek, içecek vs.'den alınan çeşitli vergilerden ibaretti. ${ }^{20}$

Temettü vergisi herkesten kazancına uygun olarak alınan vergidir. Temettuat sayımlarına göre düzenlenen yeni vergi sisteminin en önemli özelliği, vergi yükümlülüğünün şahıs bazında değerlendirilmesidir. Bu amaçla defterlerde, vergi mükellefinin adı, vergiye esas olan gelir kaynağı, kaynağın yıllık geliri ve bu gelire göre tarh eden vergi ve öşür miktarı kaydedilmiştir. Böylece; beyana dayanmayan, sayımlara göre alınan bir gelir vergisi sistemine geçilmiştir. Tanzimat ile başlayan, ödeme gücüne yönelen vergileme ilkesi yeni düzenlemelerle geliştirilmiştir. $^{21}$ Temettuat vergisi önceleri sadece Müslüman halktan alınmış ancak; Müslümanların vergiden kaçınmak için ticarethanelerini ve mal varlıklarını gayrimüslimlere devretmesiyle hazine büyük zarara uğramıştır. Böylece, yeni bir düzenlemeyle temettuat vergisinin İranlılar ve Yunanlılar hariç tüm Osmanlı halkını kapsadığı açıklanmıştır. ${ }^{22}$

\footnotetext{
${ }^{18}$ BOA, ML VRD.TMT,710:4.

${ }^{19}$ BOA, ML VRD.TMT,710:2.

${ }^{20}$ Serin.age. S.717.

${ }^{21}$ Abdullatif Şener,“ Tanzimat Dönemi Vergi Reformları”, 150. Y1lında Tanzimat, 1992, Ankara.s.102

22 Serin.age.s.721.
} 
1256/1840 yılından itibaren uygulanmaya başlayan ve bazı istisnalar haricinde ekonomik durumlarına göre herkesten alınan vergi-yi mahsusa Tanzimat idarecileri tarafından örfi vergiler yerine konulmuş olup, "An-cemaatin vergi", "Vergü-yi Mahsusa", "Vergü" ve "Komşuca alınan vergü" gibi adlar verilmiştir. ${ }^{23} \mathrm{Bu}$ verginin miktarı liva ölçeğinde belirlenirdi. Bu miktar livaya bağlı kazalar arasında paylaştırılırdı. Sonra kazanın müdür ve meclis azaları, nüfusun etnik özelliğine göre imam, papaz ve kocabaşı gibi kişilerin katıldığ1 toplantıda kasaba ve köylere düşenmiktar tespit edilir en sonunda da köy ve mahalle düzeyinde kişilerin ödeme güçlerine göre paylaştırılırdı. ${ }^{24}$

Temettu vergisi her hane reisinden kazancına uygun olarak alınan bir vergi idi. Tüccar ve esnafın yıllık kazançları tahmin ve takdir edildikten sonra başlangıçta \%3 oranında alınmış, 1878 'de \%4'e çıkarılmıştır. 1860 'tan itibaren sanat ve ticarette inhisar (tekel) kaldırılmış, bu alanda çalışanlara birer "Ruhsatiye defteri" verilerek yıllık gelirleri tahmin edilip defterlere geçirilmiştir. Temettu vergisi için esnafa "Ruhsatiye tezkeresi" adı verilen tezkereler verilmiş. $\mathrm{Bu}$ tezkereler vergi komisyonlarınca düzenlenerek esnaf kethüdaları vasıtasıyla ilgiliye teslim edilmiştir. Böylece esnaf bu tezkereye göre ödeyeceği vergiyi önceden öğrenme imkanı elde etmiş oluyordu. ${ }^{25}$

Tatlucak'ta tespit ettiğimize göre toplam vergi-yi mahsusa bedeli 3.214 kuruştur. Vergiyi mahsusa olarak en düşük vergi 64 kuruş, en yüksek vergi ise 284 kuruştur. Köyün 16 numaralı hanede kayıtlı bulunan Tercan oğlu Kalender 'in vergi-yi mahsusa bedeli olarak en düşük dilim olan 64 kuruşluk vergi bedeli takdir edildiği kaydedilmiştir. ${ }^{26} 1$ numaralı hanede kayıtlı olan muhtar Ali İmamoğlu İlyas kethüdaya ise vergi-yi mahsusa bedeli olarak 284 kuruş vergi takdir edilmiştir. ${ }^{27}$

Tablo 13. Tatlucak’ta hane reislerinin verdiği toplam öşür ve aded-i ağnam vergisi

\begin{tabular}{|c|r|c|c|c|}
\hline $\begin{array}{c}\text { Ekili tarım } \\
\text { ösrü ve aded-i } \\
\text { ağnam vergisi }\end{array}$ & $\begin{array}{c}\text { Miktar } \\
\text { (Kuruş) }\end{array}$ & Hane & Ortalama & $\%$ \\
\hline $\begin{array}{c}\text { Hunta } \\
\text { (buğday) }\end{array}$ & 642 & 20 & 32.1 & 57.01 \\
\hline Şair (arpa) & 228 & 20 & 11.4 & 20.02 \\
\hline Penbe & 91 & 20 & 4.55 & 8.08 \\
\hline Bağ & 138 & 17 & 8.11 & 12.2 \\
\hline Ağnam & 27 & 10 & 2.7 & 2.39 \\
\hline Toplam & 1.126 & & & \\
\hline
\end{tabular}

\footnotetext{
${ }^{23}$ Sait Öztürk, Temettuat Tahrirleri. Akademik Araştırmalar Dergisi Osmanlı Özel Sayısı,2000.s. 537.

${ }^{24}$ Sait Öztürk, Tanzimat döneminde bir Anadolu Şehri Bilecik. İstanbul, 1996.s. 174-175.

${ }^{25}$ Musa Çadırcı, Tanzimat Döneminde Anadolu Kentleri’nin Sosyal ve Ekonomik Yapıları, TTK Basımevi, Ankara 1991, s.346

${ }^{26}$ BOA, ML VRD.TMT,710: 7.

${ }^{27}$ BOA, ML VRD.TMT,710: 2.
} 
Toplu olarak verdiğimiz vergi türlerinden ekili tarım üzerinden alınan öşür vergisi ile alâkalı olarak hınta (buğday) \%57.01 ile ilk sırada gelmektedir.Onu \%20.02 ile şair (arpa),\% 12.2 ile bağ,\% ve \% 8.08 ile penbe (pamuk) izlemektedir. Ağnam vergisi ise \% 2.39 olarak tespit edilmiştir. Bu verilerden anlaşıldığına göre Tatlucak'ta en düşük vergi çeşidi ağnam olurken en yüksek vergi çeşidi ise hınta (buğday) olarak görülmektedir.

Tablo 14. Tatlucak’ta İkâmet Eden Kimselerin Hane Sırasına Göre Toplam Temettuatları

\begin{tabular}{|c|c|c|}
\hline $\begin{array}{l}\text { Hane } \\
\text { No }\end{array}$ & Kişi Adı & $\begin{array}{c}\text { Temettuat Toplamı } \\
\text { Kuruş }\end{array}$ \\
\hline 1 & Ali İmamoğlu İlyas kethüda & Muhtar -1455 \\
\hline 2 & Ali İmamoğlu Emin kethüda & Ziraat-608 \\
\hline 3 & Tercan oğlu molla Mustafa & Ziraat-487 \\
\hline 4 & Aşır oğlu Hüseyin & Ziraat-1218 \\
\hline 5 & Aşır oğlu Ali & Ziraat-800 \\
\hline 6 & Aş1r oğlu Süleyman & Ziraat-840 \\
\hline 7 & Köse oğlu Halil & Ziraat-485 \\
\hline 8 & Köse oğlu Hüseyin & Ziraat-392 \\
\hline 9 & Köse oğlu Hanefi & Ziraat-372 \\
\hline 10 & Köse oğlu Mehmed & Ziraat-565 \\
\hline 11 & Şah Murad oğlu Eyüb & Ziraat-909 \\
\hline 12 & Şah Murad oğlu İbrahim & Ziraat-509 \\
\hline 13 & Ali İmamoğlu Ömer & Ziraat-360 \\
\hline 14 & Ali İmamoğlu Ali & Ziraat-360 \\
\hline 15 & Zarife oğlu Veli & Ziraat-1216 \\
\hline 16 & Tercan oğlu Kalender & Ziraat-225 \\
\hline 17 & Milcan oğlu Yusuf & Ziraat-531 \\
\hline 18 & Musa koca oğlu Mehmed & Ziraat-560 \\
\hline
\end{tabular}


Rafet METIN

\begin{tabular}{|c|c|c|}
\hline 19 & Musa koca oğlu Mehmed & Ziraat-521 \\
\hline 20 & Ali İmamoğlu Süleyman & Ziraat-612 \\
\hline
\end{tabular}

\section{Sonuç}

Tatlucak karyesinin nüfusu ile ilgili olarak 669 numaralı temettuat defterinden tespit ettiğimiz kadarı ile1845 yılında Kırlangıç karyesinin 20 haneye tekâbül eden 100 neferlik nüfusu söz konusudur. Günümüzde Kırıkkale'nin Delice ilçesine bağlı olan köyün 2000 yılı adrese dayalı nüfus tesbitine göre nüfusu 175 olarak belirlenmiştir.

Tatlucak karyesindeki vergi nüfusunun tamamına yakını erkektir. Sadece köyün 15 numaralı hanesinde ikamet eden Zarife oğlu Veli anne adı ile anılmaktadır (BOA, ML VRD.TMT,710:7). İsimleri incelediğimizde Peygamber ve onun ehl-i beyti başta olmak üzere daha çok Arapça kökenli isimlerin olduğu görülmektedir. Birinci sırada Ali ismi gelmektedir. Ali ismi toplam isimlerin \%17.2'sini teşkil etmektedir. İkinci sıray $\% 10.3$ ile Aşır ismi yer almaktadır.Üçüncü sırayı ise \%6.8 ile Mehmed ve Hüseyin isimleri gelmektedir. Tabloda zikredilen isimler arasında Tercan ve Kalender gibi isimler o dönemde yörede kullanılan ender isimler olarak karşımıza çıkmaktadır.

Tatlucak karyesinin iktisadi ve sosyal yapısıi ncelendiğinde geçim kaynağının tarım ve hayvancılığa dayalı olduğu görülmektedir. Ziraî üretimin en önemli kısmını ekili tarım alanları oluşturmaktadır. Ekili tarım alanları bakımından Tatlucak’ta başta buğday olmak üzere arpa, penbe (pamuk) üretilmektedir. Ekili (tarla) tarım alanları 872 dönüm olup 9.210 kuruş gelir elde edilmiştir. 25 dönüm bağdan 2.070 kuruş gelir elde edilmiştir.

Tatlucak'ta toplam 581 olan hayvan varlığının büyük çoğunluğunu küçükbaş hayvanlar oluşturmaktadır.\%75.2'si küçükbaş (437 adet), \% 17.9'u büyükbaş (104 adet) ve \% 8.6's1 yük ve binek (50 adet) hayvanı olarak sıralanmaktadır. Büyükbaş hayvan çeşidinde, karasığır öküzü, sağman inek ve kısır inek ön planda yer alırken küçükbaş hayvan çeşidinde ise, koyun, keçi ve kuzu tercih edilmektedir.Binek ve yük hayvanı olarak isemerkep başta olmak üzere, deve, kısrak ve katır beslenmektedir.

Tatlucak'ta hayvancılık hasılatında ilk sırayı binek hayvanlar almaktadır (3.130 kuruş). İkinci sırada küçükbaş hayvanlar (1.629 kuruş) ve üçüncü olarak büyükbaş hayvanları gelmektedir (940 kuruş).

Tatlucak'ta vergi türlerinden ekili tarım üzerinden alınan öşür vergisi ile alâkalı olarak hınta (buğday) \%57.01 ile ilk sırada gelmektedir.Onu \%20.02 ile şair (arpa),\% 12.2 ile bağ,\% ve \% 8.08 ile penbe (pamuk) izlemektedir. Ağnam vergisi ise \% 2.39 olarak tespit edilmiştir. $\mathrm{Bu}$ verilerden anlaşıldığına göre Tatlucak'ta en düşük vergi çeşidi ağnam olurken en yüksek vergi çeşidi ise hınta (buğday) olarak görülmektedir.

Miktarı liva ölçeğinde belirlenen ve livaya bağlı kazalar arasında paylaştırılan vergi-yi mahsusa bedeli olarak Tatlucak'ta tespit ettiğimize göre toplam vergi-yi mahsusa bedeli 3.214 kuruştur.

Sosyal yapı olarak bakıldığında Tatlucak'ta köse, şah, milcan, tercan gibi lakaplar muhtemelen ailelerin geçmişten beri kullana geldikleri lakaplar olarak görülmektedir.

Sonuç olarak Orta Anadolu'da küçük ölçekli bir köy olan Tatlucak'ın 1844-1845 y1lları arasında sosyo-ekonomik yapısı ortya konulmaya çalışılmıştır. Bu vesile ile ileride yapılacak çalışmalara bir nebzede olsa katkı sunmak hedeflenmiştir. 


\section{Kaynakça}

\section{Belgeler}

BOA, ML VRD.TMT,710.

\section{Makale ve Kitaplar}

Barkan, Ö. L., (1953). Tarihî demografi araştırmaları ve Osmanlı tarihi (Cilt: X). İstanbul: Türkiyat Mecmuas1.

Bozkurt, N. (2011). T1844-1845 Tarihli Temettuat Defterine Göre Kütahya Sancağ 1 Dazkırı Kazası Evciler Köyünün Sosyal ve Ekonomik Yapısı, Uluslararası Sosyal Araştırmalar Dergisi, 4 (19): 135-156.

Çadırcı, M, (1991). Tanzimat Döneminde Anadolu Kentleri'nin Sosyal ve Ekonomik Yapıları, TTK Basımevi, Ankara,s.346.

Devellioğlu, F. (1996), "Temettü'-Temettüat", Osmanlıca - Türkçe Ansiklopedik Lügat (13. Baskl.) Ankara: Aydın Kitabevi Yayınları,

Gül, A. (2009). Temettuat Defterlerine Göre Pasinler'in (Hasankale) Sosyal ve Ekonomik Yapıs1 . Karadeniz Araştırmaları, 6 (23): 77-98.

Güran, T. (2000). “19. Yüzyıl Temettuat Tahrirleri”, Osmanlı Devleti’nde Bilgi ve İstatistik, Ankara,s.77-78.

Kankal, A. (1998).Kırıkkale Tarihine Dair Araştırmalar I: İskân, OTAM, Sayı: 9: 225-239

Kütükoğlu, M. (1995). “Osmanlı Sosyal ve İktisadî Tarihi Kaynaklarından Temettü Defterleri”, cilt LIX/225, Belleten, Ankara, s. 394-412.

Özer, İ. (2000). Temettuat Defterlerinde Somuncu Babanın Nesebi (1844),Akademik Araştırmalar Dergisi , s.4-5: 593-609.

Öztürk, S. (1996). Tanzimat döneminde bir Anadolu Şehri Bilecik. İstanbul, s. 174-175.

Öztürk, S. (2000). Temettuat Tahrirleri. Akademik Araştırmalar Dergisi Osmanlı Özel Say1s1,s. 537-591.

Kızılkan, A. Ö.(2008). Osmanlı Vergi Düzeninde Temettuat 198 Uygulamaları Üzerine Bir Değerlendirme", Dumlupınar Üniversitesi Sosyal Bilimler Dergisi, sayı:20, 57- 66,

Metin, R. (2018). 1260-61 / 1844-45 Temettuat Kayıtları Işı̆̆ında Kazmaca Köyü, Studies of the Ottoman Domain Volume-Cilt: 8 / Issue-Say1: 15 /s.193.

Serin,M .(1998). "Osmanlı Arşivi'nde Bulunan Temettuat Defterleri” T.C. Başbakanlık I.Millî Arşiv Şûrası (20-21 Nisan 1998) Tebliğler Tartışmalar, T.C. Devlet Arşivleri Genel Müdürlüğ̈̈ Yayınları, Ankara.s.717-728.

Şener A.“ Tanzimat Dönemi Vergi Reformları”, 150. Y1lında Tanzimat, 1992, Ankara.s.102 
Ek 1-2: Temettuat Defter örnekleri

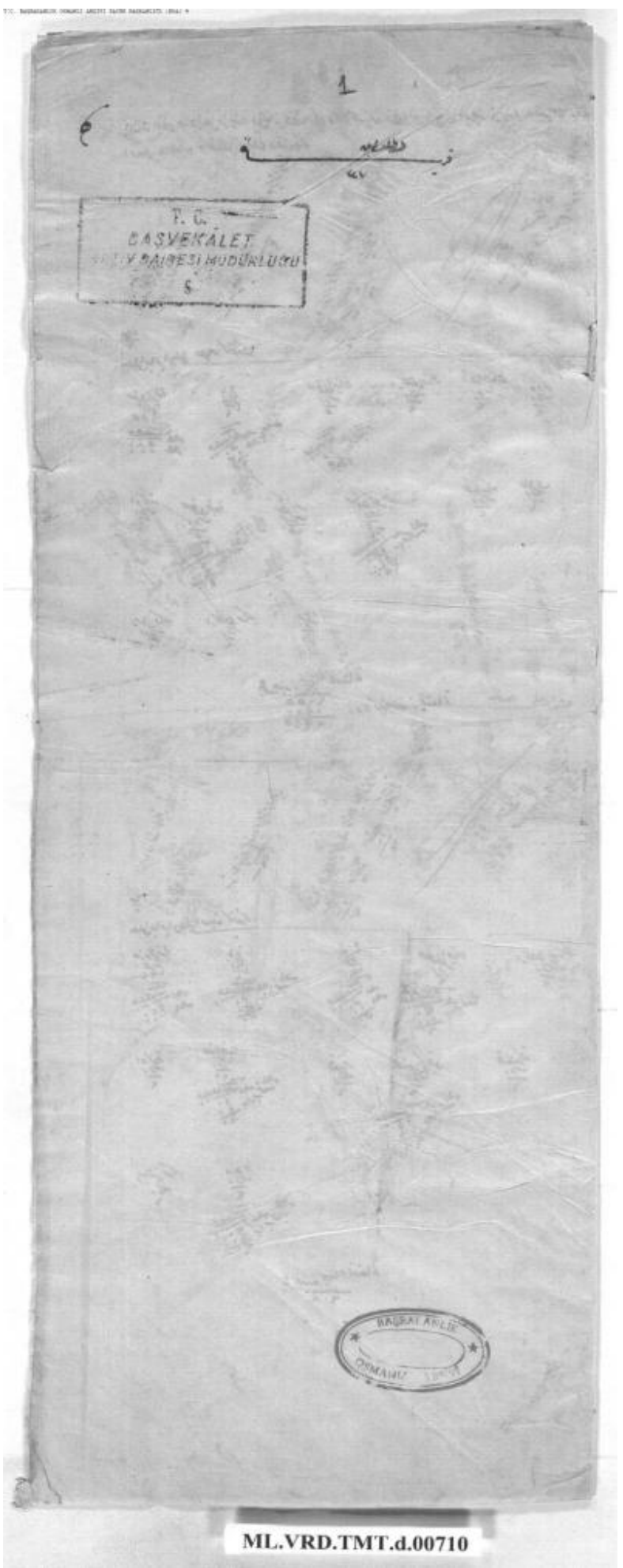




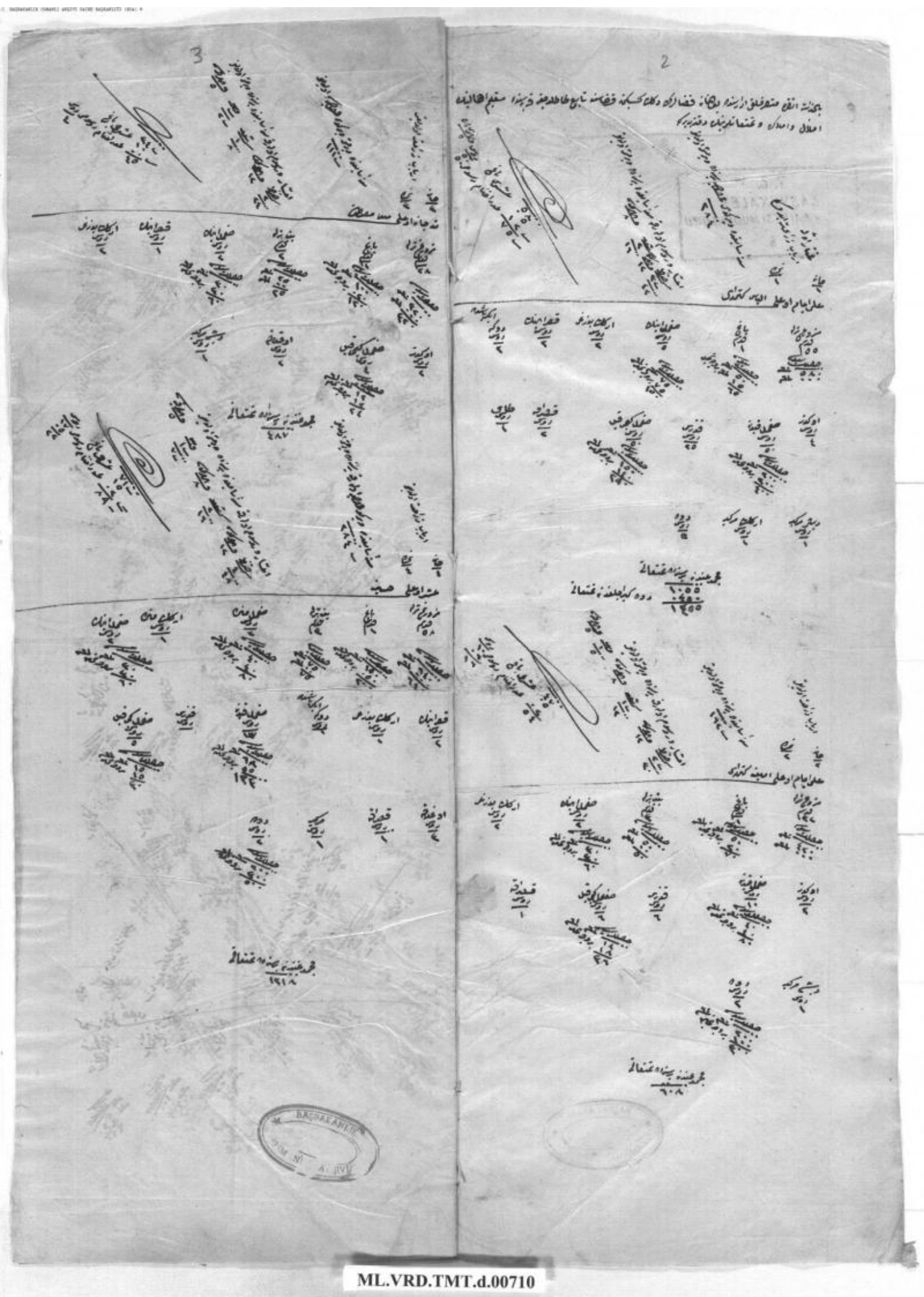




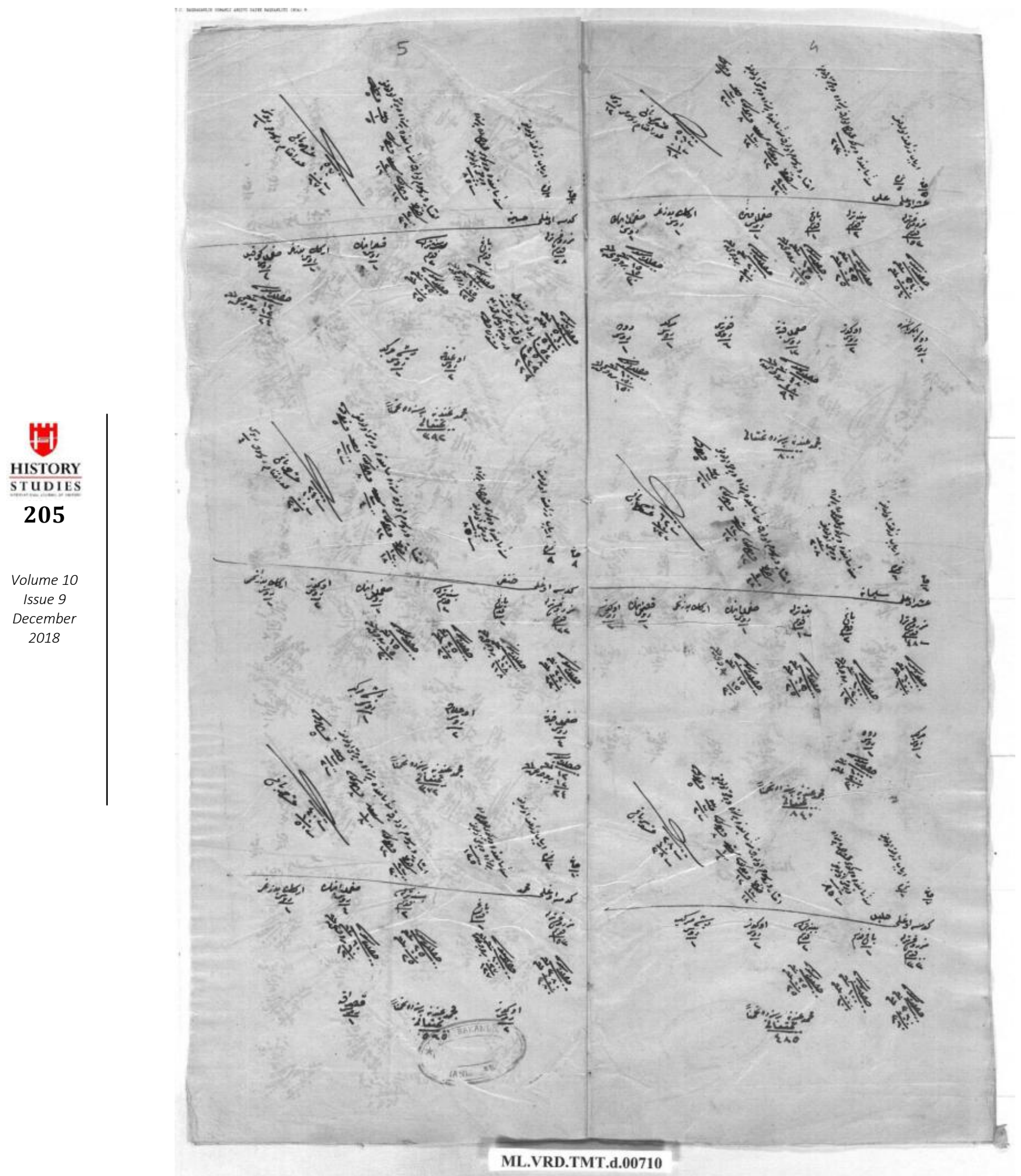

